have prevented this good result. In the management of the a bove case I had the benefit of several consultations with Dr. Cheadle, to whom my best thanks are due for much valuable assistance and advice.

[NoTE - Writing on May 2nd, patient states that a large amount of fluid was withdrawn from the left pleura in January, that no signs of phthisis are present, and that he is well and strong.]

Carlton-hill, N.W.

\section{A CASE OF CERVICAL DISLOCATION.}

\section{BY DONALD MACPHAIL, M.D.GLAS.}

The following case is worth recording from the severity of the effect produced by a trivial cause.

Late on a Saturday night in April I was hurriedly called to see a man "In a fio" at a barber's shop in the village here. When I arrived at the place I found, extended on the floor, the dead body of a man whom I had known by sight for the last ten years. He was a collier, a strong healthy man, aged fortythree, about $5 \mathrm{ft} .9$ in. in height, and weighed probably between $11 \frac{1}{2}$ 'and $12 \mathrm{st}$. He had al ways been a heavy drinker, but had otherwise been healthy. Those present told me that he had been lying on the floor for some time, supposed to be in a drunken sleep. It was evideno that he had been dead for some time. The face was pale, with some faint, livid blotches, and there was a slight bruise on the left temple, the eyes were closed, and the pupils normal in size; the lips were blue, but the mouth was closed, and there was no froth about it; the tongue was not protruded or between the teeth; the moustache was saturated with coluurless fluid, which had apparently flowed from the nostrils. There was no evidence of the man having vomited. My first thought was that he had been suffocated, and I tried to examine his throat. I found it very difficult to get my finger down between the back of the tongue and the back of the pharynx, and impossible to reach the glottis. There was no foreign matter to be felt. This state of affairs was very puzzling for a moment, but on turning the body on its face and palpating the back of the neck it was at once evident that there was displacement of the fourth cervical vertebra forwards to a very considerable extent. The body was at once removed, and attempt made to get a clear history of the accident. That was difficult to do in the midst of an excited crowd, some of whom were inclined to raise the question of foul play. I obtained an outline of the history at the time, however; and the police, by visiting a considerable number of persons during the night, were able to get details, all the different witnesses giving almost exactly the same story. The man had come into the shop very drunk, but able to talk, and had been shaved. He then made for the door, but some acquaintance waiting in the shop advised him to stay there, lest he might be apprehended as "drunk and incapable," for it was evident to them that he was getting more and more drunk every minute. He was led to " the waiters' bench," a long form, about fifteen inches high and nine inches wide, which was set close against a wall, and sat there for a short time till he fell off. He was helped up, apparently none the worse for that fall, and set upon the bench again with his legs stretched out straight in front of him, and his head banging limply on his breast. In a few minutes he slipped forwards, without making any efforb to save himself, and came down heavily in a sitting posture on the floor, his head being jerked back violently by the fall. He sat for a moment and then rolled over on his left side on the floor, "drawing his legs and arms up like one suffering from cramp" as he did so. He was allowed to lie, as those present thought there was no use setting him up so often, and he lay there for nearly two hours, till someone, coming in at the door and stumbling over his feet, drew attention to his stillness and pallor. I saw him a few minutes after that. No one had seen him move after the second fall. He had not vomited, and no one had noticed whether he was breathing or not while he lay on the floor. Next evening, with the aid of my assistant, Dr. James Muir, I made a post-mortem examiaation, which was a very imperfect one, for it had to be done in a small room, by dim lamplight, and in the presence of the dead man's brother. We made a longitudiual incision along the spine, and dissected away the soft parts on both sides. We found the fourth cervical vertebra displaced so far forwards as to allow $\mathrm{my}$ finger to freely enter the spinal canal in the fifth vertebra, the spinous process of the fourth resting upon the upper surface of the body of the fifth. The cord seemed to be completely divided. We felt the bones all round, but could find no evidence of fracture or of disease in the spines, transverse processes, or bodies of the vertebre. No external marks of violence could be found on carffal examination, except the slight bruise on the left temple and a doubtful one on the left side of the nose.

Whether this man died direetly from the injury or from suffocation as he lay io would be difficult to say positively. It is well known that dislosation of the spine at this level is not necessarily immediately fatal, but the completeness of the displacement and of the rupture of the spinal cord may have cansed death by shock. The "spasm" in which he rolled over on the floor suggests that he died at that time. I once saw an infant die instan. taneously from an injury to the medulla oblongata or cervical cord, and it died with just such a spasm of the flexor muscles of the limbs. At all events, the appearance of this man's body did not suggest rapid suffocation as the cause of death. This case of fatal injury from a slight cause was made the more impressive to us from our having to examine next day a woman who had tried to commit suicide by jumping from a railway bridge, over $30 \mathrm{fb}$. high, on to the rails, but had fortunately sustained only a slight scalp wound and a thorough shaking.

Whifflet, Lanarkshire.

\section{Altiror

$$
\text { or }
$$

\section{HOSPITAL PRACTICE,}

\section{BRITISH AND FOREIQN.}

Nulla autem est alla pro certo noscendi via, nisl quamplurimas et mor, oorum et dissectionum historias, tum aliorum tum proprias collecta. habere, ot inter se comparare.-MORGAGN De Sed, et Canss. Morb., lib. iv. Propemium.

\section{SEAMEN'S HOSPITAL, GREENWICH.}

ANEURYSM OF COMMON CAROTID ARTERY; LIGATURE OF ARTERY; RECOVERY.-EPITHELIOMA OF LIP AND OF

PENIS IN A MAN AGED TWENTY-FOUR.

(Under the care of $\mathrm{Mr}, \mathrm{G}$. R. Turner.)

ThIs was a very large carobid aneurysm, probably from its rapid growth traumatic in origin; and although on the right side of the nesk, the internal jugular vein lay slightly to the inner side and in frons of the carotid artery at the point where the ligature was applied to the vessel. It is difficult to see how this anatomical abnormality could have been caused by the ancurysm, as the sac had by its inward pressure caused considerable displacement of the larynx. F or more than three weeks after the operation the size of the aneurysm remained nearly the same. This inactivity was then followed by a most rapid shrinkage and hardening of the sae, and consequent return of the larynx to the middle line; so that six weeks after the operation the man's neck was quite normal in appearance. Mr. Turner intended to have used a kangaroo tendon ligature, but not being able to get one exactly suited he substituted a stout catgut one. For the notes of the cases we are indebted to Mr. Jervis.

CASE 1.-B. B-, aged twenty-nine (?), boatswain, a native of Manilla, was admitted to hospital on Dec. 1lth, 1891. The history of the case is imperfect and the details doubtful, as no competent interpreter could be found. Previous history : There was a doubtful history of syphilis but no signs could be found. For about two months the man had had a rather rapidly growing swelling in the right side of the neck, wbich had lately caused cough, some difficulty in breathing, and very severe shooting pains over the right side of the head and face. An cfficer of the ship who brought the man up remarked, "The abscess is ready to be cut, as we have kept poultices on it for a week."

On admission a tumour about the size of a clenched fist was found occupying the right side of the neck. It 